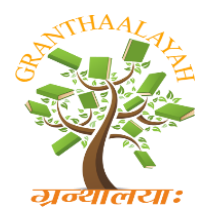

INTERNATIONAL JOURNAL OF RESEARCH GRANTHAALAYAH A knowledge Repository

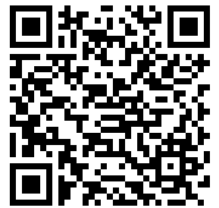

Management

\title{
MOBILE SUBSCRIBERS' SATISFACTION TOWARDS SERVICE QUALITY IN TUTICORIN DIST
}

\author{
Asst. Prof. S. Anthony Rahul Golden *1 \\ ${ }^{* 1}$ Head, Department of Commerce, Dean of Students, Loyola College, Namakkal, INDIA
}

\begin{abstract}
Due to huge competition in the service sector, service providers have to focus on lots of aspects in connection with satisfying the customer. Especially, the providers need to focus on increasing the service quality to maintain their position in the competitive market. Subscribers' satisfaction is one of the determinants of service quality and perception carried by subscribers plays an important role in choosing a mobile service provider. This paper presents a service quality analysis of mobile subscribers in Tuticorin Dist.
\end{abstract}

Keywords:

Subscribers, Service, Quality, Market, VAS \& Mobile.

Cite This Article: Asst. Prof. S. Anthony Rahul Golden, "MOBILE SUBSCRIBERS' SATISFACTION TOWARDS SERVICE QUALITY IN TUTICORIN DIST" International Journal of Research - Granthaalayah, Vol. 4, No. 4: SE (2016): 1-5.

\section{INTRODUCTION}

As today's market is customer oriented, quality is the indication of success and survival of a product or service. These days, service quality has become an important research topic in view of its significant relationship to cost, profitability, customer satisfaction, customer retention, service guarantees and financial performance. Quality is the real advertisement for every service and goods. Without quality the future of the company will be questionable. The service sector is expanding at an increasing rate and is becoming intensely competitive (Chen, et.al., 1994; Johnson, et.al., 1988). As such, service quality has become a very important issue in marketing and has received much attention due to being deregulated and thus has increased the competition among service providers (e.g.: health care, banking and telecommunications in the 1980's and utilities in the 1990's). Service quality has become so important that some businesses, not only need high levels of service quality for success, but in some cases, need it for survival.

\section{OBJECTIVES OF THE STUDY}

- To assess the factors determining the choices of a service providers.

- To study the subscribers' attitude towards providers services. 
- To identify the problems those are being faced by the subscribers.

- To offer suggestions to overcome the problems.

\section{STATEMENT OF THE PROBLEM}

"The greatest satisfaction is depending upon the quality of the service. Quality is the state of complete positive and favourable thoughts towards the given service. Good quality is one of the most crucial components of retaining the subscribers. Every subscriber possesses the right to get proper and standard service. Over the last decades, quality is decreasing for everyday. There are a number of service providers and there is severe competition among these service providers. It is in the context the study has been undertaken, to find out the service quality in mobile communication service providers in Tuticorin Dist.

\section{SCOPE OF THE STUDY}

The scope of the study is confined to the service quality in service providers in Tuticorin District. In Tuticorin District there are good numbers of mobile subscribers in both urban and rural areas, having advanced technology communication equipment. Both the government and private service providers have been included in this study. Further, the study is confined to factors that influence the subscribers to select a particular service operator and the subscribers' attitudes towards various mobile service providers. As regards subscribers' attitude towards quality, the study is confined to the problems that are faced by them in availing mobile communication services.

\section{ANALYSIS AND INTERPRETATION}

\section{LEVEL OF SATISFACTION ON SERVICE QUALITY}

The service quality has a significant role in satisfying the consumers. The quality determines the product or services to withstand in the market for a longer course of time. Thus, the future of the service provider entirely depends on the quality of the service rendered by the mobile communication service provider. Therefore, the researcher has analysed the satisfaction of the respondents regarding service quality.

Table 1: Level of satisfaction on service quality

\begin{tabular}{|c|c|c|c|c|c|c|c|c|}
\hline \multicolumn{3}{|c|}{ Service Quality } & HDS & DS & $\mathbf{N}$ & $\mathbf{S}$ & HS & Total \\
\hline \multirow{4}{*}{$\begin{array}{l}\text { Quality of } \\
\text { SMS }\end{array}$} & \multirow{2}{*}{$\begin{array}{l}\text { Public } \\
\text { sector }\end{array}$} & Count & 4 & 30 & 46 & 16 & 8 & 104 \\
\hline & & $\%$ within & 3.8 & 28.8 & 44.2 & 15.4 & 7.7 & 100 \\
\hline & \multirow{2}{*}{$\begin{array}{l}\text { Private } \\
\text { sector }\end{array}$} & Count & 26 & 141 & 232 & 93 & 130 & 622 \\
\hline & & $\%$ within & 4.2 & 22.7 & 37.3 & 15.0 & 20.9 & 100 \\
\hline \multirow{4}{*}{$\begin{array}{l}\text { Quality of } \\
\text { value added } \\
\text { service }\end{array}$} & \multirow{2}{*}{$\begin{array}{l}\text { Public } \\
\text { sector }\end{array}$} & Count & 2 & 1 & 15 & 71 & 15 & 104 \\
\hline & & $\%$ within & 1.9 & 1.0 & 14.4 & 68.3 & 14.4 & 100 \\
\hline & \multirow{2}{*}{$\begin{array}{l}\text { Private } \\
\text { sector }\end{array}$} & Count & 6 & 29 & 247 & 256 & 84 & 622 \\
\hline & & $\%$ within & 1.0 & 4.7 & 39.7 & 41.2 & 13.5 & 100 \\
\hline \multirow{2}{*}{$\begin{array}{l}\text { Clarity of } \\
\text { signal and }\end{array}$} & \multirow{2}{*}{$\begin{array}{l}\text { Public } \\
\text { sector }\end{array}$} & Count & 6 & 31 & 51 & 15 & 1 & 104 \\
\hline & & $\%$ within & 5.8 & 29.8 & 49.0 & 14.4 & 1.0 & 100 \\
\hline
\end{tabular}




\begin{tabular}{|l|l|l|l|l|l|l|l|l|}
\hline connection & Private & Count & 44 & 65 & 156 & 291 & 66 & 622 \\
\cline { 3 - 10 } & sector & $\%$ within & 7.1 & 10.5 & 25.1 & 46.8 & 10.6 & 100 \\
\hline \multirow{3}{*}{$\begin{array}{l}\text { Quality } \\
\text { Internet }\end{array}$} & $\begin{array}{l}\text { Public } \\
\text { sector }\end{array}$ & Count & 1 & 2 & 26 & 61 & 14 & 104 \\
\cline { 2 - 10 } & \multirow{2}{*}{$\begin{array}{l}\text { Private } \\
\text { sector }\end{array}$} & Count & 31 & 50 & 113 & 309 & 119 & 622 \\
\cline { 3 - 10 } & \% within & 5.0 & 8.0 & 18.2 & 49.7 & 19.1 & 100 \\
\hline
\end{tabular}

Source: Computed Primary Data

The above table shows that

a) Quality of SMS: In the public sector, 44.2 per cent of the respondents are neutral, 28.8 percent of the respondents are dissatisfied, 15.4 percent of the respondents are satisfied, 7.7 percent of the respondents are highly satisfied and 3.8 per cent of the respondents are highly dissatisfied with the quality of SMS. In the private sector, 37.3 per cent of the respondents are neutral, 22.7 percent of the respondents are dissatisfied, 20.9 percent of the respondents are highly satisfied, 15 percent of the respondents are satisfied and 4.2 per cent of the respondents are highly dissatisfied with the quality of SMS.

It is inferred that 44.2 per cent of the public sector respondents are neutral and 37.3 per cent of the private sector respondents are neutral with quality of SMS.

b) Quality of value added services: In the public sector, 68.3 per cent of the respondents are satisfied, 14.4 percent of the respondents are highly satisfied, 14.4 percent of the respondents are neutral, 1.9 percent of the respondents are highly dissatisfied and 1.0 per cent of the respondent is dissatisfied with the quality of value added service. In the private sector, 41.2 per cent of the respondents are satisfied, 39.7 percent of the respondents are neutral, 13.5 percent of the respondents are highly satisfied, 4.7 percent of the respondents are dissatisfied and only one per cent of the respondents are highly dissatisfied with quality of value added service.

It is inferred that 68.3 per cent of the public sector respondents are satisfied and 41.2 per cent of the private sector respondents are satisfied with the quality of the value added service.

c) Clarity of signal and connection: In the public sector, 49 per cent of the respondents are neutral, 29.8 percent of the respondents are dissatisfied, 14.4 percent of the respondents are satisfied, 5.8 percent of the respondents are highly dissatisfied and only one per cent of the respondents are highly satisfied with the clarity of signal and connection. In the private sector, 46.8 per cent of the respondents are satisfied, 25.1 percent of the respondents are neutral, 10.6 percent of the respondents are highly satisfied, 10.5 percent of the respondents are dissatisfied and 7.1 percent of the respondents are highly dissatisfied with the clarity of signal and connection.

It is inferred that 49 per cent of the public sector respondents are neutral and 46.8 per cent of the private sector respondents are satisfied with the clarity of signal and connection.

d) The quality of internet: In the public sector, 58.7 per cent of the respondents are satisfied, 25 percent of the respondents are neutral, 13.5 percent of the respondents are highly satisfied, 1.9 
percent of the respondents are dissatisfied and only one per cent of the respondents are highly dissatisfied with quality of internet. In the private sector, 49.7 per cent of the respondents are satisfied, 19.1 percent of the respondents are highly satisfied, 18.2 percent of the respondents are neutral 8 per cent of the respondents are dissatisfied and 5.0 percent of the respondents are highly dissatisfied with quality of internet.

It is inferred that 58.7 per cent of the public sector respondents are satisfied and 49.7 per cent of the private sector respondents are satisfied with quality of internet.

\section{Ranking on factors Influencing satisfaction towards service quality}

Table 2: Ranking on factors Influencing satisfaction towards service quality

\begin{tabular}{|l|l|l|l|l|}
\hline \multirow{2}{*}{ Service Quality } & \multicolumn{2}{|l|}{ Public Sector } & \multicolumn{2}{l|}{ Private Sector } \\
\cline { 2 - 5 } & Mean Score & Rank & Mean Score & Rank \\
\hline Quality of SMS & & & & \\
\hline Quality of value added service & 3.77 & III & 2.29 & IV \\
\hline Clarity of signal and connection & 2.88 & II & 3.61 & II \\
\hline Quality of internet & 3.81 & IV & 3.43 & III \\
\hline
\end{tabular}

Source: Computed Primary Data

From the above table it is clear that in the public sector, quality of the internet has the first rank followed by quality of value added services, quality of SMS and clarity of signal and connection, whereas in private sector quality of the internet has the first rank followed by quality of value added services, clarity of signal and connection and quality of SMS.

In both sectors, quality of the internet is mostly influenced in the satisfaction of the respondents.

\section{FINDINGS}

- 44.2 per cent of the public sector respondents are neutral and 37.3 per cent of the private sector respondents are neutral with quality of SMS.

- 68.3 per cent of the public sector respondents are satisfied and 41.2 per cent of the private sector respondents are satisfied with the quality of the value added service.

- 49 per cent of the public sector respondents are neutral and 46.8 per cent of the private sector respondents are satisfied with the clarity of signal and connection.

- $\quad 58.7$ per cent of the public sector respondents are satisfied and 49.7 per cent of the private sector respondents are satisfied with quality of internet.

- In Both sectors, among all factors, quality of the internet is mostly influenced in the satisfaction of the respondents.

\section{CONCLUSION}

Thus, it concludes that service quality occupies the major role in subscribers' satisfaction. It the critical task to each and every operator to provide quality service to their subscribers in mobile communication. Quality will increase the quantity of the mobile subscribers. So the mobile subscribers have to concentrate on SMS service because it is in the neutral stage and they have to 
strengthen the following area i.e. value added service, signal \& connection and internet. If the operator provides better service, then the subscribers will satisfied. If the subscribers satisfied, then they will continually have service. Thus, the operators can have their subscribers for the upcoming periods.

\section{REFERENCE}

[1] Akbar, M. M., \& Parvez, N. (2009). Impact of service quality, trust, and customer satisfaction on customers loyalty. ABAC Journal, 29(1).

[2] Chakraborty, S., \& Sengupta, K. (2014). Structural equation modelling of determinants of customer satisfaction of mobile network providers: Case of Kolkata, India. IIMB Management Review, 26(4), 234-248.

[3] Chuang, Y. F. (2011). Pull-and-suck effects in Taiwan mobile phone subscribers switching intentions. Telecommunications Policy, 35(2), 128-140.

[4] Golden, S. A. R. (2015). Regional Imbalance affecting quality of e-banking services with special reference to Tuticorin District-An Analysis. International Journal of Research, 2(3), 788-798.

[5] Golden, S. A. R. (2016). Mobile Subscribers' Satisfaction Towards Offers. Shanlax International Journal of Arts, Science \& Humanities.

[6] GOLDEN, S. A. R., \& GOPALAKRISHNAN, D. SUBSCRIBER'S PERCEPTION TOWARDS CUSTOMER CARE SERVICE IN MOBILE TELECOMMUNICATION WITH SPECIAL REFERENCE TO TUTICORIN CITY. CHIEF PATRON CHIEF PATRON.

[7] Golden, S. A. R., \& Regi, S. B. (2015). Satisfaction of Customers towards User Friendly Technological Services offered by Public and Private Sector banks at Palayamkottai, Tirunelveli District. International Journal of Research, 2(3), 775-787.

[8] Golden, S. A. R., \& Regi, S. B. Mobile Commerce in Modern Business Era.

[9] Negi, R. (2009). DETERMINING CUSTOMER SATISFACTION THROUGH PERCEIVED SERVICE QUALITY: A STUDY OF ETHIOPIAN MOBILE USERS. International Journal of Mobile Marketing, 4(1).

[10] Prof. S. Anthony Rahul Golden, "MOBILE SUBSCRIBERS' ATTITUDE TOWARDS SERVICE TARIFF WITH SPECIAL REFERENCE TO TUTICORIN DIST” International Journal of Research - Granthaalayah, Vol. 4, No. 3: SE (2016): 1-6.

[11] Regi, S. B., \& Golden, S. A. R. (2014). Attitude of Rural People Towards Technology Inclusion In Banking Services At Tirunelveli District. IGJAE - Indo Global Journal Of Applied Management Science, 2(2).

[12] Regi, S. B., \& Golden, S. A. R. (2014). Customer Preference towards E- Channels Provided By State Of Bank Of India.

[13] Regi, S. B., \& Golden, S. A. R. (2014). Customer Preference Towards Innovative Banking Practices Available In State Bank Of India At Palayamkottai. Sankhya International Journal Of Management And Technology, 3(11 (A)), 31-33.

[14] Sarkindaji, B. D., Hashim, N. A. B., \& Abdullateef, A. O. (2015). Assessing Efficiency of Service Quality on Consumers Retention in Nigerian Mobile Service Industry. Mediterranean Journal of Social Sciences, 6(1), 195. 